\title{
The Social Construction of Parents' Sexual Education in Bugis-Makassar Families
}

\author{
A Octamaya Tenri Awaru \\ Department of Sociology Education, Faculty of Social Science, \\ State University of Makassar, 90222, Makassar, Indonesia \\ Corresponding Author: a.octamaya@unm.ac.id
}

\section{ARTICLE INFO}

\section{Publication Info:}

Research Article

How to cite:

Awaru, A. O. T (2020). The Social Construction of Parents' Sexual

Education in Bugis-Makassar

Families. Society, 8(1), 175-190.

DOI : 10.33019/society.v8i1.170

Copyright $\odot$ 2020. Owned by Author(s), published by Society

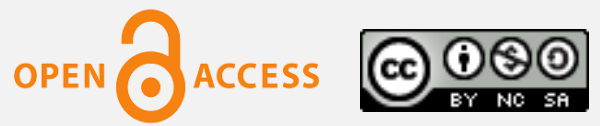

This is an open-access article.

\author{
License: Attribution- \\ NonCommercial-ShareAlike \\ (CC BY-NC-SA)
}

\begin{abstract}
False interpretations of sex make sex education less prioritized by parents in educating their children. This condition is considered as the cause of increased child abuse, violence, and sex crimes. This research aims to reveal the social construction of parents' sexual education Bugis-Makassar families. The research used a qualitative approach with the paradigm of constructivism. The analysis model was conducted through the interpretation and understanding of data collected through interviews and observations. The informants were selected using a purposive sampling technique with the informants' criteria were the parents in Bugis-Makassar families and have children between the ages of 13-25 years old and also live in the city of Makassar. Data verification was conducted through the persistence of observation and triangulation of time. The data obtained were analyzed through three stages, which consist of data reduction, data presentation, and drawing conclusions. The results showed different construction of each parent according to the level of information and experience they had. Construction occurs simultaneously in three stages, which consist of externalization, objectification, and internalization. The most prominent stage is the objectification stage, which then forms four constructions, which consist of 1) sexual education is teaching about genitals; 2) teaching of sexual intercourse procedures; 3) the distinction of male and female roles, and; 4) the process of teaching manners to associate with the opposite gender. In its implementation, the internalization stage is not maximal due to parental experience, false understanding of sex, fear of parents, child misinterpret the information provided, and lack of knowledge about sexual education.
\end{abstract}


Received: April 29, 2020;

Accepted: May 28, 2020;

Published: June 29, 2020;
Keywords: Parents; Sexual Education; Social Construction

\section{Introduction}

The originator of sexual education in Indonesia was the Faculty of Medicine, Padjadjaran University. On this campus, sexual education began to be discussed in a lecture entitled "Sex Education Issues". This activity was precisely held on September 9, 1972 (Sa'abah \& Malian, 2001). Although this issue has been discussed for more than 20 years, it remains controversial in Indonesian society. Most people assume that sex is not something to teach but it will be known along with the child's growth or development.

Parents are very instrumental in providing sex education to their children. Parents are the first and foremost educators for children and the family is the first social environment for children. The family is the main part of socialization. It is following research conducted by Foucault (2000) which stated that parents and relatives are the primary agents for the spreading of interesting sexuality beyond the support of doctors, educators, and psychiatrists. Similarly, the results of research by Sifa (2019), Safita (2013), Ambarwati, (2013), Septiawan et al. (2014), Putri et al, (2015), Abduh \& Wulandari (2016) explained that a family is a place that should provide sex education to teenagers.

The research results conducted by Zelnik \& Kim proved that when parents can accept a child's interest in sexuality, and have the desire to discuss sexuality with them, then the child tends to postpone the first intercourse sex (Helmi \& Paramastri, 2015). Sex education obtained by teenagers from their parents makes them responsible for the sex education they get. Responsible sex knowledge by teenagers is expected to form healthy sexual behavior and not engage in premarital sexual behavior.

Some parents still lack in understanding the importance of sex education. Negative views of parents about sex make sexual education in families rejected and ignored by parents. So, teenagers tend to get information about sex from friends, magazines, and the Internet. Though the information obtained may be wrong and could even lead to pornography.

The current condition of parenting roles in providing sex education has been taken over by the mass media. The accuracy of information from the mass media is still questionable. Finally, many teenagers misunderstand this information. This is because many news and realities of life around us, which visualize children as victims of promiscuity, abuse, violence, and sexual crimes. This should be a barometer for parents to increasingly realize that the problem of sexuality is a threat to the younger generation, both in terms of social relations and health. To reduce their impact, parents should change their views on sexual education.

Weak sex education in the family is caused by the negative stigma of the community about sex. Talks or discussions about sex are still considered taboo even for educational purposes. As a result, teenagers rarely got enough knowledge about sex from their parents (Fitriana, 2012; Mertia et al., 2011). Ultimately, the problem will lead to unexpected sexual behavior.

Parents seem reluctant and embarrassed in discussing sexually related matters with their children. Many parents do not understand the purpose of sexual education. On the other hand, many studies have found that one of the causes of increasingly teenagers free sex behavior and sexual harassment and crimes due to lack of education or correct sexual information received by children from parents, schools, and the community (Mertia et al., 2011; Sulandjari, 2017; Satria \& Elsera, 2017).

Copyright (C 2020. Owned by Author(s), published by Society. This is an open-access article under the CC-BY-NC-SA license. 
The lack of sexual education given by parents to children is a reality that is the result of social construction in the community. Sexual education is formed from social construction internalized by individuals. By following the concept of Peter L. Berger, sex education is a concept that is jointly created between an individual, in this case, a parent, with his sociocultural environment.

Sex education is not a natural reality, but a product of discourse systems and practices that forms supervision and control to individuals, which are increasingly intensive. By itself, sexuality is a game because it is limited by space and time (Siahaan, 2015). Space and time can change the human image and perception about the meaning of sexuality education.

The city of Makassar is one of the metropolitan cities in Indonesia, which most of the people have a high level of education. Although the community is classified to have a middle and high-level education but the acceptance of sexual education in the family is still lacking. This is due to the misinterpretation of sex as well as the experience of education from previous generations which did not prioritize sex education to children. This condition is described in the research conducted by Prawirohardjo on free sex behavior in the city of Makassar revealed that free sex behavior is increasingly widespread and overtly done by teenagers caused by the lack of functioning of one of the social structure in the community i.e. family where a) sex education in the family is less effective even there is information that they never get sex education, b) parental supervision dimensions are not optimal, and c) the family as a problem-solving place lack of response to conducted in a full and continuously (Awaru et al., 2018).

Similarly, the research conducted by Nurhidayah \& Agustang (2018) and Astiwi \& Awaru (2018), which revealed that parents know that sexual education is important for children. However, they feel uncomfortable to talk about it during the child's development. Parents have more trust and give entirely to teachers to teach sex education in schools.

Sexual education in Bugis-Makassar families is not a priority. In educating their children, parents in Bugis-Makassar families tend to keep away their children from matters related to sexuality. This is due to the narrow-minded interpretation of sex. Sex is always identified with intercourse. Thus, sex is considered unnecessary to be discussed or taught to unmarried children. Questions from children related to sex tend to be avoided by parents. Finally, children make social media and peers as a way out to find information related to sex. Although the information provided by the mass media and peers can be interpreted incorrectly by children.

Sex is a sacred thing and only for those who have married in Bugis-Makassar families. However, sexual education should be given to children from an early age. Sex education is needed to bridge the curiosity. This aims to allow the child to have self-esteem, to have confidence, and to focus on increasing the ability to make good decisions about sex. The main thing is to keep children away from free sex behaviors, harassment, violence, and sexual crimes.

Therefore, in this research, parents placed as the central point of research. It aims to describe the construction process of parents' sexual education in Bugis-Makassar families individually. The results of this research are expected to build awareness to parents on the importance of guiding the knowledge of sex education to teenagers today and to build awareness to shape and change existing constructions to suit the educational needs of teenagers in the modernization era to avoid free sex behavior.

\section{Literature Review}

\subsection{Peter L. Berger and Thomas Luckmann's Theory of Social Construction}

The social construction of Peter L. Berger and Thomas Luckmann is one of the theories born to a phenomenological approach. The common thread and meeting point of the ideas of Karl 
Marx, Émile Durkheim, and Max Weber were elaborated by Peter L. Berger and tended to ignore the paradigmatic contradictions. Peter L. Berger and Thomas Luckmann tried to describe that there are two main objects of reality that relate to knowledge, consisting of 1) 1) individual knowledge which is the construction of the definition of reality that belongs to an individual or subjective reality which is then constructed through an internalization process, and 2) objective reality which is then interpreted as a social fact. The complexities of defining reality as well as the routines of patterned actions and behaviors are all internalized by the individual in general as a fact or an objective reality (Berger \& Luckmann, 1990; Sulaiman, 2016).

Studies on the sociology of knowledge described three concepts or commonly referred to as three dialectics (Berger \& Luckmann, 1990) consisting of first, externalization in which the process begins with several actions conducted by a group of humans. These actions will be repeated by humans if they assume their actions are appropriate and can solve the problems they are experiencing at the time. Adaptation externalization is a moment where a person adapts himself to the social environment. The process of applying ideas to reality is called externalization.

Second, objectification occurs after repeated actions are consistently performed. Humans will formulate the facts that occur due to the rules that govern this awareness because of repeated and consistent actions. Objectification is the process of crystallizing objects into the mind of all externalization processes that have been performed or seen in reality in the environment objectively, making it possible for new meanings or additional meanings. According to Ngangi (2011), there is a distinction between two social realities at this moment, which consists of individual self-reality and other social realities that are outside the individual, which then makes this reality become something objective. Third, internalization shows that humans are the product of society. The function of internalization is to transmit the institution as a stand-alone reality and internalization occur through the mechanism of socialization. Internalization is an individual process as a subjective reality in interpreting objective reality. In other words, the human effort is in reabsorbing reality, then once again transforming it from an objective reality structure into a subjective reality structure.

The dialectical cycle is seen in these three stages in the relationship between humans and society where humans form society and then humans are formed by society. These three stages will continue and are related to one another and eventually, the process will return to the internalization stage and will continue. In the end, individuals can form new meanings and behaviors if there are new values. The explanation described by Peter L. Berger and Thomas Luckmann about three dialectics concluded that the individual is actually the product and the social institution creator.

Peter L. Berger and Thomas Luckmann's theory of social construction on reality was chosen in this research because the description of the concepts described in the theory is considered to be very suitable or relevant to the reality to be studied, which is in-depth research of the social construction of parents' sexual education in the city of Makassar, especially in Bugis-Makassar families. Berger \& Luckmann (1991) stated that a reality that occurs in society is the result of construction by the community itself. In this case, the reality of the meaning of sexual education by parents in the city of Makassar will be described according to the description of Peter L. Berger's three dialectic stages, which consist of externalization, objectification, and internalization. 


\subsection{Sexual Education}

Sex education is the provision of information or knowledge relating to the issue of human sexuality. This knowledge according to Sarlito (2012) includes the process of conception, pregnancy to birth, sexual behavior, sexual intercourse, health, psychiatric, and societal aspects. It is supposed that the issue of sexual education provided relates to the norms and rules of the community that teaches about permissible and prohibited things and how to do it without violating the rules of the community.

Gawshi as cited in Madani (2003) stated that sex education is the process of providing true knowledge to children with the aim that children can adapt and have a good sexual attitude in the future of their lives. Sarwono (2010) stated that good sexuality education provided to teenagers should include prevailing norms in the community that teaches about permissible and prohibited things and how to do it without violating the rules of the community. It is one of the solutions offered to stem the orientation trend to pseudo pleasure, commercialization, and fabrication of sexuality in children, especially teenagers. Sexual education is expected to change attitudes and prepare children to have self-determination and inner strength to every desire and will.

The direction and purpose of sex education activities should be well planned and carefully so that it is expected to be achieved properly. Direction assignments and objectives are used to measure the success of sex education. According to Rosyid (2007), there are six sex education objectives, consisting of a) Providing a correct understanding of sex education materials including an understanding of reproductive organs, adult identification, sexual health, sexual deviations, pregnancy, childbirth, puerperal, purification, and marriage; b) Overrule the public's view of sex education which is considered taboo, un-Islamic, unethical and so on; c) Understanding of sex education materials essentially understands the teachings of Islam; d) The sex education material provided is adjusted to the age of the child who knows to place himself in the environment; e) Being able to anticipate adverse effects due to sexual deviations, and f) being a healthy generation.

Dianawati (2003) also described the purpose of sexual education in teenagers, including a) teenagers are expected to obtain true, clear, and accurate knowledge of sexual life such as reproductive organs and its functions and treatments, sexually transmitted diseases (STDs), healthy sexual behavior, and so on; b) Teenagers are expected to manage their sexual desires appropriately; c) Healthy behavior related to sexual life (can care for and look after it); d) Able to properly obey religious law relating to their sexual life; e) Did not engage in promiscuity and abuse their sexual life, f) Can avoid deviant sexual behavior such as masturbation habits, sodomy, incest (sexual relations or marriage between two biological siblings who are deemed to violate custom, law, or religion) and; g) Avoid immoral acts or adultery.

Based on the concepts of sex education above, it is concluded that sex education is a process of transmitting values and directing the sexual behavior of children by providing various kinds of supporting material such as about the occurrence of physical and psychological changes and about the function of reproductive organs and the importance of caring for and take care of the organ. In sex education is also taught about social values, religion, morals, customs, and law. It is intended that children can protect themselves from the "wrong" sexual behaviors that are not in accordance with the norms prevailing in the community.

\subsection{Sex in Bugis-Makassar Community}

One of the basic human needs is sex. Its position is the same as the food and clothing needs. Terminologically, sex is lust. Sex is a driving force of human life and is commonly called an

Copyright (C) 2020. Owned by Author(s), published by Society. This is an open-access article under the CC-BY-NC-SA license. 
instinct which is owned by men and women. This instinct then encourages both men and women to continue their descent.

Many of us have heard sexually motivating stories that describe the meetings of men and women. The story of Romeo and Juliet, Cleopatra and Mark Antony, Paris and Helen, and many other stories. Similar stories also occur in Bugis-Makassar community, for example in the story of I La Galigo, which tells about the meeting Sawerigading from Luwu to China to marry a Chinese princess named We Cudai (Hadrawi et al., 2008).

The ancient script that describes sex culture is also owned by Bugis-Makassar community. The sex manuscript of Bugis-Makassar community is called Assikalaibineng, a text describing public knowledge about the relationship between husband and wife in all aspects. This is a special entry that tells the story of sex education that uses the Lontara script in Bugis and Makassar language. Assikalaibineng plays a role $\mathrm{n}$ shaping the culture and sexuality behavior of Bugis-Makassar community. Nevertheless, the knowledge of Assikalaibineng is still a very confidential and specific thing. Knowledge of sex is a secret and specific thing that has been institutionalized in the living system of Bugis-Makassar community.

In daily life, Bugis-Makassar community upholds their cultural values. Rahim (2011) explained that there are six values used as guidelines in behaving in Bugis Makassar community, which consist of honesty value (alempureng), intellectual value (amaccang), propriety value (asitinajang), determination (agettengeng), effort (reso), and self-esteem, shame (siri).

In implementing sex education, the values used as the main guidelines are the propriety value (asitinajang) and the value of self-esteem, shame (siri). The concept of the propriety value (asitinajang) is related to appropriate or inappropriate. Sex in Bugis-Makassar community is considered an inappropriate subject to be discussed in public especially to be discussed with unmarried children. So, the value of propriety (asitinajang) is related to space and time. There are times and places that are considered appropriate and inappropriate for discussing sex. For people who often talk about sex without seeing the place and time are usually referred to in Bugis language as mangure (always obscene-minded) or in Makassar language called lale (flirty/always-obscene minded).

For Bugis-Makassar community, sex is related to self-esteem, shame (siri). Talking about things related to sex is considered a shameful thing. Awaru (2019) argued that the meaning of sex for Bugis-Makassar community is self-esteem, shame (siri). Violations that occur related to sex are always associated with self-esteem. For example, women who have been married and then committed adultery, in the past, will be condemned to death by being drowned. Though in the present day, it will usually end at the tip of a knife (badik) because it is considered to trample her husband's pride or humiliate her husband.

This value develops and institutionalized in Bugis-Makassar community which then becomes the reason sex from the times to times was never taught to unmarried children. Talking about sex is only consumption for married people not for teenagers, especially early childhood.

\section{Research Methodology}

This research aims to understand the social construction of parents' sexual education in Bugis-Makassar families. Thus, the research paradigm considered being relevant as the basis or reference for this research is the constructivism paradigm. Guba et al., (1994) suggested that in epistemology, the constructivism paradigm applies the principle of hermeneutical and dialectical in the process of discovering the truth. Hermeneutic constructivism is used to

Copyright (C) 2020. Owned by Author(s), published by Society. This is an open-access article under the CC-BY-NC-SA license. 
interpret, explain, and uncover the meaning of the concept of sexual education or the phenomenon of sexual education that is taboo provided to children in the community's perception. Operationally, the research approach used is qualitative.

This research was conducted in the city of Makassar, South Sulawesi Province, Indonesia. The research subjects were spread in 14 districts in the city of Makassar. The informants of this research were parents in Bugis and Makassar tribes in the city of Makassar, who were able to articulate their views. Bugis and Makassar families are the focus of research because these two tribes are the dominant tribes domiciled in the city of Makassar. Criteria for informants in this research are a) Parents who have a high school/vocational or bachelor education and understand the meaning of sexual education to children, b) Coming from several different professions, c) Having a boy or girl, aged 13-25 years.

In-depth interviews and observations are the methods used to collect data. Interviews were conducted in two ways: autoanamnesa (interviews with subjects or informants) and alloanamnesa (interviews with informants' families). Observations are made to observe, formulate, and find meaning, material, and methods of sexual education that are constructed on the parents which then is applied by parents in their children's education process.

Data were analyzed using an interactive analysis model, which consists of data reduction, data display, and drawing conclusion/verification (Miles \& Huberman, 1994). Data collection, which is data collected from informants through interview and observation techniques, after the data has been successfully collected from the research process such as interview transcripts and observations result which are still in form of raw materials, then an analysis of the data is collected both at the time of research in progress and when the field research is over. Data reduction, at this stage, research data is already in the form of patterns and categorizations based on research substance which includes the construction of sexual education through externalization, objectification, and internalization stages. Data display, which consists of organizing data, creating into patterns, creating brief descriptions, charts, and relationships between categories. Data that have been organized are then analyzed to find the essence of sexual education construction, which is the analysis of actors from construction buildings and to classify actors who play a role in shaping sexual education construction in parents as recipients of sexual education discourse. Conclusions, after the presentation of the data, a conclusion will be drawn to answer the problem formulation and provide suggestions based on the results of research and conclusions drawn. Data validation or data verification is done by persistence observation and triangulation of sources and time (Moleong, 2014).

\section{Results and Discussion}

Sex education is a process of transmitting values and directing the sexual behavior of children with various supporting material. In sexual education, children are provided knowledge about social values, religion, morals, customs, and law. The construction of sexual education in Bugis-Makassar families varies. However, in general, or most of the construction of sexual education as something that is not important for provided to children. Children will know by themselves as the age progresses. The construction of parents' sexual education in the Bugis-Makassar families, in this research, can be categorized into four different categories: first, Bugis-Makassar parents which construct that sexual education is teaching about genitals. This can be seen from the results of the interview below:

"Sex education, as far as I know, is to inform children about their genitals", (Interview, KT, 54 years).

Copyright (C 2020. Owned by Author(s), published by Society. This is an open-access article under the CC-BY-NC-SA license. https://doi.org/10.33019/society.v8i1.170

181 
"Telling children about 'memek', 'burung', and its functions, in my opinion, is sexual education", (Interview, AN, 52 Years).

One of the interesting things is that parents in their discussions about genitals to their children, they use figurative words. For example, vaginal or female genital are delivered with the figurative name such as "bembeng", "memek", or "tempe". As for the boys, the penis is delivered as "burung". These other names of genitals are delivered to their children because they feel more polite in saying it.

In Bugis community, the value of shame (Siri) has developed, which is held firmly in daily life. The genitals for the Bugis-Makassar community are Siri. That is, issues related to genitals are a matter of self-esteem. The issue of sex is a closed matter. Sex in Bugis-Makassar community is a sacred thing so discussing it openly is a shame (Hadrawi et al., 2008).

The habit of explaining the names of genitals to children continues for generations. In fact, according to the informant, this is not a problem for them because the figurative names of genitals have been commonly used in Bugis-Makassar community. Informing the child the correct name of the genitals is a necessity so that the child does not experience confusion over their body. The genital identification is limited to the name of the genitals, and not by the actual name.

Second, Bugis-Makassar parents construct that sexual education is teaching sexual intercourse procedures. This can be seen from the interview results of several informants as follows:

"In my opinion, sex education is provided to children about the process of intercourse conducted", (Interview, FW, 49 years).

"How I educate my children about sex when they are not married. Sex education is telling the children about sexual intercourse procedures. If the child wants to get married, then I can tell them", (Interview, JA, 52 years).

Talking about sex is considered an adult conversation. Early childhood and unmarried teenagers are considered inappropriate for getting sexual information. Though, children need to be provided education about sex from an early age to protect them from sexual harassment, violence, and sexual crimes. As a result of research conducted by Simon \& Daneback (2013), which stated that early childhood and teenagers were very vulnerable to becoming victims of abuse, violence, and sexual crimes.

Parents in this category are only ready to provide sexual education to their children who will and have been married. Parents in this category assume that sexual education is talking about husband and wife relationships. Therefore, sexual education will only be provided to children who are getting married or are married. These results are relevant to research conducted by Rahman (2014) which explained that in Bugis community, sexuality including sexual intercourse is sacred and related with dignity and self-esteem, which is conducted in marriage between women and men. This means, sex in Bugis-Makassar community only belongs to those who are married. Talking about sex with unmarried children is considered as a taboo or shameful thing. They believe that children who already have sexual knowledge at a teen's age will make children always think obscene or in Bugis language called mangure and in Makassar language called lale. 
When the child will get married or married, parents assume it is the most appropriate time to provide education to their children about sexual knowledge. Alang (2005) explained that in Lontara Assikalaibingeng (sexual ethics of Bugis community) ethics in sexual intercourse are important things to know before getting married. The most emphasized thing in sexual intercourse is not forgetting Allah SWT during the process of sexual intercourse.

At the time before marriage, parents will provide their children knowledge about the procedures for sexual intercourse, good and bad times in sex, procedures for cleaning the body, even the procedure for sex that can determine the genitals of children. Such knowledge is given coincided with prayers and sex mantras.

Third, Bugis-Makassar parents construct that sexual education is teaching distinction the roles of men and women. This can be seen from the results of the interview as follows:

"Sex education, in my opinion, is to teach children how the nature of origin, its role as a man and as a woman. This is important to understand children. In my opinion, this is part of sexual education", (Interview, PI, 52 years).

"Children are told about how they behave as women or as men. Teach their role in the family, I think, that is meant as sex education", (Interview, MP, 48 Years).

Parents who construct sexual education is teaching distinction the roles of men and women are parents who initially also get information from their parents that sex is taboo and not to be discussed. However, they have been informed about the importance of sexual education from social media and friends who work as health workers. They have been given an education that conducting sexual education approach for children is one way to prevent sexual violence against children.

In the objectification stage, parents are afraid of the increasing number of news about sexual harassment, violence, and crime that make children victims. From the incident, they then look for information on how to prevent child promiscuity and keep children away from child predators. Therefore, informants consider that it is very necessary to increase their knowledge or insight related to sex.

In the internalization stage, in this case, the parents make an introduction to the role of the child although it is still in a simple way. This sexual information provided by parents starting at an early age. Even the introduction of this role tends to put girls in an inferior position. For example, by advising that cooking is a must for girls because they have to serve their husbands and take care of their children. Women's duties are in the kitchen and don't need to pursue education. In educating their children, informants perceive that girls must have tenderness, have a high sense of empathy, must have compassion, and do more activities at home. Toys for girls are dolls, cookware toys and wear ribbons in their hair. Whereas for the boys, games played are directed outside the home such as playing marbles, toy cars, toy robots, and soccer. Boys are required to be assertive, self-reliant, brave, and strong. Boys must look after girls and girls become children who must be looked after.

Fourth, Bugis-Makassar parents construct that sexual education is a process of teaching manners to associate with the opposite sex. They are parents who already have adequate sexual knowledge. As the following interview results:

"Sexual education is important to me. I work as a nurse. So I often get information about sexual education. Essentially, in sex education, it teaches children in 
associating, both with same-sex and opposite-sex, attitudes toward older and younger people", (Interview, ASH, 49 years).

Parents no longer only consider sex education to be related to gender or intercourse. Parents in this category have obtained information relating to sexual education even though the information was not obtained directly but through social media intermediaries. This construction is heavily influenced by information obtained outside of the family environment.

Similar to the previous category, the objectification stage in this category, parents try to find information about how to communicate properly and correctly about sex education to children. Parents consider it necessary to provide their children with sexual education due to increased promiscuity. Information about sexual crimes that often occur to children makes them afraid so they try to find solutions to avoid it. Social media exposure has a significant effect on the decision.

In the internalization stage, parents provide sexual knowledge to children related to social relationships, especially when the child growing up in a teenager and begin to enter puberty. They conveyed manners in associating with members of the opposite sex which were sometimes affirmed with threats or intimidation. In the internalization stage, parents begin to give an understanding to children about which parts of the body may or may not be touched by others, appropriate and inappropriate touches, accustom children to cover up aurat (parts of the body that cannot be seen (according to Islamic law)) and provide examples of good relationships and bad relationships and their consequences.

In introducing puberty to their children, the informant's parents conveyed it when their children had entered the phase so that their children did not have the readiness to accept it. This happens because parents consider their children are still young and not the right time to talk about puberty and other physical changes.

The four social constructions of parents' sexual education in parents are formed through three simultaneously stages on parents as individuals, which consist of 1) the externalization stage, 2) the objectification stage, and 3) the internalization stage.

\subsection{Externalization Stage}

Externalization is a stage where someone adapts themselves to their social environment. In this research, externalization is the beginning of social construction in the community. Externalization in this case is in the form of a process of adaptation to the sacred texts, the agreement of scholars, laws, norms, values, policies, realities that are outside human beings, prevailing in the community.

The externalization stage in this research showed that from the beginning the informants were educated by their parents that talking about matters relating to sex was not allowed. Speaking sex publicly or openly is considered a sin or violates religious law. Every time a child tries to ask something about sex then the parent will rebuke or forbid it.

"From childhood, in my family, you can't talk about sex, usually when I or my sister/brother asks, parents will rebuke or get angry", (Interview, AET, 46 years).

In educating their children, the informant's parents gave an understanding that sex was related to genitals and the process of intercourse between men and women. This narrow-minded understanding related to sex education results in closed sexual issues for parents to discuss with their children. 


\subsection{Objectification Stage}

The objectification stage occurs after the individual repeats the action consistently. With this awareness of repeated and consistent actions, humans will realize that reality is due to the rules that govern them. The objectification stage allows the occurrence of new meanings or additional meanings of the social facts.

The objectification stage in this research is that the parents' view of sex education is following their initial knowledge of sex taboo meaning which then becomes an objective reality. In the objectification stage, parents' views differ from one another. The difference in views depends on experience, education, and information obtained from the local environment. This phenomenon is relevant to the theory of social construction that in the stage of objectification, individual knowledge differs from one another depending on influence factors outside the individual (Berger \& Luckmann, 1991).

In this research, the most prominent stage is the objectification stage where children adopt parents' actions and continue from childhood to adulthood. Sexual issues do not need to be taught to children, because children will know by themselves, have been constructed for a long time to parents in Bugis-Makassar families.

This objectification stage then crystallized some of the same views from informants about sexual education which were then classified into four categories, which consist of 1) parents' objectification which constructs sexual education is teaching about genitals; 2) the objectification of parents which construct sexual education is teaching sexual intercourse procedures; 3 ) parents' objectification which constructs sexual education is teaching distinction the roles of men and women; 4) the objectification of parents which construct sexual education is a process of teaching manners to associate with the opposite sex.

In the objectification category, parents who construct sexual education is teaching about genitals and sexual intercourse procedures are parents who have very little sexual education knowledge and information. They consider that sex education is only a matter that teaches about genitals to children and related to sexual intercourse. This is because these parents only get information about sex-based on educational experience from their parents who only say that sex is taboo to talk about. Parents in this category are those who have never received good and correct information about sexual education, both from schools and the mass media.

Educational experience gained from their parents continues to be upheld and considered the best way in the child's educational process. Parents introduce genitals when their children are still in the early childhood category.

This explains that in the objectification stage, informants are heavily influenced by their parents' upbringing. Parents feel no need to convey to children about the name of the genitals because, in the end, the child will find out by itself.

In the objectification category, parents which construct sexual education is teaching distinction the roles of men and women and a process of teaching manners to associate with the opposite sex are parents who have received information and have received socialization about the importance of sexual education, both in schools, mass media, and from their profession. They get sexual education information from mass media such as television, newspapers, magazines, and social media. According to them, in the current condition, social media is the most media that presents information about sexual education such as Facebook, Whatsapp, and Instagram. 


\subsection{Internalization Stage}

Internalization is the last stage of human in interpreting the social reality around them. In this stage, an individual will absorb everything objectively and then will be realized subjectively. Internalization continues for an individual's lifetime through socialization. In the internalization process, each individual has a difference in the dimensions of their absorption. Some absorb more external aspects, but some absorb more internal aspects that can be obtained by individuals through primary and secondary socialization processes.

In this research, parents' stages of internalization in Bugis-Makassar families differ from one another. This difference is influenced by the stage of objectification that they conducted. At first, the knowledge of parents or research informants was the same, which was to assume that sexual education was a taboo subject to be discussed especially to be discussed with children. However, after obtaining various information in the objectification stage which in the implementation differs from one another, so that in the internalization stage then found subjective realities that differ from their initial views on sexual education. Although in the end, the knowledge they get about sexual education does not affect their actions to maximize sexual education to children. Parents feel awkward and uncomfortable to start talking about matters relating to sex, especially to their unmarried children or are still early childhood and teenagers.

The results found that, overall, the research informants were able to define sexual education although the implementation is not maximal. The stage of internalization that is not maximal is also caused by the experience of parenting from their parents. The value in the family, which should not discuss sex in the spaces moreover to be taught is a legacy in primary relationships as stated by Bungin (2005) that in primary social groups the social relations that occur are still very strong and are top-down or from parent to child or from the previous generation to the next generation. This supports the results of research conducted by Ulfiah (2016) which stated that the family as the first socialization agent for children never teaches a person or their children to take actions that are contrary to the value of propriety. The family even teaches and encourages their children to act, say, and behave following the norms prevailing in the community.

The second factor is the incorrect perception or understanding of sex, which considers sex as merely sexual intercourse. This assumption caused Bugis-Makassar community to feel taboo to discuss sex. For Indonesian or in eastern cultures, which still uphold good manners, speaking of sex is an unethical matter especially when it is discussed in public spaces. Nyarko et al, (2014) stated that several factors influence parents' decisions in providing sex education, one of which is the general perception of the community. The perception that developed in the community, from the past to the present, that sex is something related to intercourse. Of course, at present, this perception is considered wrong. But in the past, this perception was the right thing and should not be opposed.

The third factor is the stages of internalization were not maximal, which is the fear of the parents that the child will misinterpret the information provided. Because of the lack of knowledge about good and correct sexual education, parents are ultimately afraid to discuss sex with children. They are afraid of the way they are doing is wrong so that the child will be wrong in receiving information or sexual knowledge that they provide. The fourth factor is the lack of knowledge about good and correct sexual education.

The findings of this research are relevant to the social construction theory of Berger \& Luckmann (1991) which stated that in daily life, humans have been provided with the reality as well as the knowledge that will be used as guidelines in daily life and maintaining their behavior. The objective reality in daily life then interpreted by the individual. This means that

Copyright (C 2020. Owned by Author(s), published by Society. This is an open-access article under the CC-BY-NC-SA license. 
the interpretation is subjective. Social facts are constructed by individuals based on their will. Poloma (2007) stated that social construction is a social process through actions and interactions where individuals continuously create a reality that is shared and subjectively experienced together.

Social construction is a process of meaning conducted by individuals on the environment and aspects outside of itself, namely the subjective meaning and objective reality in the consciousness of people who carry out their life activities. Humans shape society, as well as society forms humans, it runs simultaneously in the stages known as externalization, objectification, and internalization.

In Bugis-Makassar community, sex has always been a taboo. A thriving reality which then forms a construction that sex is not to be discussed openly, including parents to children even for educational purposes. In Bugis-Makassar community, a perception was created that sexual knowledge will be acquired naturally as a child's growth and development.

It is accepted and acknowledged by most communities by most people, but not all, some reject and feel the need to give their children sexual knowledge. Different meanings of each individual are determined by experience, education, and information obtained during their life. This condition is following Berger \& Luckmann (1990) which stated that in the construction of reality, individuals have different meanings according to the experience they get.

The most influential actor in the construction of sexual education establishment on informant was family or parents. Besides, mass media is the second actor which is influential in the construction of sexual education establishment. According to Harris \& Scott (2002) and Mashudi (2015) stated that media such as television, newspapers, magazines, and social media are media to obtain information about sex education. Besides, health workers are a source of information about sexual education.

The externalization, objectification, and internalization stages expressed by Berger and Luckmann were not always occurring simultaneously. But in this research reveals the process that occurs according to logical stages, externalization produces objectification, objectification results affect internalization. The internalization stage is a basic part for individuals to conduct the re-externalization process.

\section{Conclusion}

The construction of parents' sexual education in Bugis-Makassar families proceeded through three stages, which consist of the externalization, objectification, and internalization stages. The construction process is influenced by several things, which include the educational experience of their parents, information from social media, and socialization from health workers. The initial knowledge of parents is that sex is a taboo thing to talk about especially to be taught to children. In the objectification stage, perceptions begin to be influenced by various information and then produce subjective realities that are different from the initial realities that they understand.

In the objectification stage, there is a different construction of sexual education even though there are still parents who still construct sexual education as their initial views. There are four construction of sexual education found, which consist of 1) sexual education is teaching about genitals; 2) sexual education is a teaching procedure for sexual intercourse; 3) sexual education is teaching distinction the roles of men and women.; and 4) sexual education is the process of teaching manners to associate with the opposite sex. 
In practice, the internalization stage is still not maximal due to parental experience, parental beliefs or misconceptions about sex, fear of parents, children misinterpret the information provided, and lack of knowledge about good and correct sexual education.

\section{Acknowledgment}

The author would like to thank all the informants who provided assistance and information during the research conducted.

\section{Declaration of Conflicting Interests}

The author declared no potential conflicts of interest concerning the research, authorship, and/or publication of this article.

\section{References}

Abduh, M., \& Wulandari, M. D. (2016). Model Pendidikan Seks Pada Anak Sekolah Dasar Berbasis Teori Perkembangan Anak. Seminar Nasional Pendidikan Berkemajuan dan Menggembirakan (The Progressive E Fun Education Seminar) Ke-1 "Jati Diri LPTK PTM untuk Pendidikan yang Berkemajuan dan Menggembirakan". Medan, Indonesia: Asosiasi LPTK Perguruan Tinggi Muhammadiyah, Majelis Diktilitbang PP Muhammadiyah, Universitas Muhammadiyah Surakarta, Universitas Muhammadiyah Sumatera Utara. Retrieved from http:/ / hdl.handle.net/11617/7832

Alang, S. (2005). Etika Seksual dalam Lontara: Telaah Pergumulan Nilai-Nilai Islam dengan Budaya Lokal (Cet. II ed.). Makassar, Indonesia: Coraq Press.

Ambarwati, R. (2013). Peran Ibu Dalam Penerapan Pendidikan Seksualitas Pada Anak Usia Pra Sekolah (Di TK SBI Kroyo, Karangmalang, Sragen). Konferensi Nasional PPNI Jawa Tengah "Closing The Gap: Millenium Development Goals and Increase Quality of Practice Nurses". Semarang, Indonesia: Persatuan Perawat Nasional Indonesia Jawa Tengah. Retrieved from http://103.97.100.145/index.php/psn12012010/article/view/875

Astiwi, A., \& Awaru, A. O. T. (2018). Pengaruh Pengetahuan Orangtua Terhadap Penerapan Pendidikan Seks Dalam Keluarga Di Kelurahan Tamarunang Kecamatan Mariso Kota Makassar. Jurnal Sosialisasi: Jurnal Hasil Pemikiran, Penelitian dan Pengembangan Keilmuan Sosiologi Pendidikan, 5(3), 55-58. Retrieved from https://ojs.unm.ac.id/sosialisasi/article/view/12378/7294

Awaru, A. O. T. (2019). Rekonstruksi Pendidikan Seksual Pada Orangtua di Kota Makassar. Universitas Negeri Makassar.

Awaru, A. O. T., Idris, R., \& Agustang, A. (2018). Sexual Education at High School Sinjai East. Proceedings of the 1st International Conference on Social Sciences (ICSS 2018), 944-947. Paris, France: Atlantis Press. https://doi.org/10.2991/icss-18.2018.196

Berger, P. L., \& Luckmann, T. (1990). Tafsir Sosial Atas Kenyataan: Risalah tentang Sosiologi Pengetahuan (terj. H. Basri). Jakarta: LP3ES.

Berger, P. L., \& Luckmann, T. (1991). The Social Construction of Reality: A Treatise in the Sociology of Knowledge. London, United Kingdom: Penguin Book Ltd.

Bungin, B. (2005). Pornomedia: sosiologi media, konstruksi sosial teknologi telematika E perayaan seks di media massa. Jakarta: Kencana.

Dianawati, A. (2003). Pendidikan seks untuk remaja. Jakarta: Kawan Pustaka.

Fitriana, N. G. (2012). Hubungan pengetahuan dan sikap tentang seks pranikah dengan perilaku seksual pada siswa SMK XX Semarang. Jurnal Komunikasi Kesehatan Edisi 4, 3(1), 
1-13. Retrieved form http://e-journal.akbidpurworejo.ac.id/index.php/jkk4/article/view/30

Foucault, M. (2000). Seks dan Kekuasaan (terj. S.H Rahayu). Jakarta: Gramedia.

Guba, E. G., Lincoln, Y. S., \& Denzin, N. K. (1994). Competing Paradigms in Qualitative Research. Handbook of Qualitative Research. Thousand Oaks, California: Sage Publications.

Hadrawi, M., Rachman, A. J., \& Agus, N. (2008). Assikalaibineng: kitab persetubuhan Bugis. Makassar: Ininnawa.

Harris, R. J., \& Scott, C. L. (2002). Effects of Sex in the Media. In J. Bryant, D. Zillmann, \& M. B. Oliver (Eds.), Media Effects: Advances in Theory and Research (2nd Edition, pp. 307-331). Abingdon, United Kingdom: Taylor \& Francis. https://doi.org/10.4324/9781410602428

Helmi, A. F., \& Paramastri, I. (2015). Efektivitas pendidikan seksual dini dalam meningkatkan pengetahuan perilaku seksual sehat. Jurnal Psikologi, 25(2), 25-34. Retrieved from https://dev.jurnal.ugm.ac.id/jpsi/article/view/7502

Madani, Y. (2003). Pendidikan seks untuk anak dalam Islam: panduan bagi orang tua, guru, ulama, dan kalangan lainnya. Jakarta: Pustaka Zahra.

Mashudi, E. A. (2015). Pencegahan Kekerasan Seksual Pada Anak Melalui Pengajaran Personal Safety Skills. Metodik Didaktik: Jurnal Pendidikan Ke-SD-an, 9(2), 60-71. Retrieved from http://jurnal.upi.edu/md/view/3490/Pencegahan\%20Kekerasan\%20Seksual\%20Pada\%2 0Anak\%20Melalui\%20Pengajaran\%20Personal\%20Safety\%20Skills

Mertia, E. N., Hidayat, T., \& Yuliadi, I. (2011). Hubungan antara Pengetahuan Seksualitas dan Kualitas Komunikasi Orangtua dan Anak dengan Perilaku Seks Bebas pada Remaja SiswaSiswi Man Gondangrejo Karangnyar. WACANA, 3(2), 109-136. Retrieved from http://jurnalwacana.psikologi.fk.uns.ac.id/index.php/wacana/article/view/40

Miles, M. B., \& Huberman, A. M. (1994). Qualitative data analysis: An expanded sourcebook. Thousand Oaks, California: Sage Publications.

Moleong, L. J. (2014). Metodologi Penelitian Kualitatif (Ed. 33). Bandung: PT. Remaja Rosdakarya.

Ngangi, C. R. (2011). Konstruksi sosial dalam realitas sosial. Agri-Sosioekonomi, 7(2), 1-4. https://doi.org/10.35791/agrsosek.7.2.2011.85

Nurhidayah, I., \& Agustang, A. (2018). Pendidikan Seks Bagi Anak Remaja (Studi Pada Orangtua Berpendidikan Menengah Di Kelurahan Karuwisi Kecamatan Panakkukang Kota Makassar. Jurnal Sosialisasi: Jurnal Hasil Pemikiran, Penelitian dan Pengembangan Keilmuan Sosiologi Pendidikan, 5(1), 62-67. Retrieved from https:/ / ojs.unm.ac.id/sosialisasi/article/view/12203/7209

Nyarko, K., Adentwi, K. I., Asumeng, M., \& Ahulu, L. D. (2014). Parental attitude towards sex education at the lower primary in Ghana. International Journal of Elementary Education, 3(2), 21-29. https:/ / doi.org/10.11648/j.ijeedu.20140302.11

Poloma, M. (2007). Margaret, Sosiologi Kontemporer (terj. Yasogama). Yogyakarta: Raja Grafindo Persada.

Putri, S. E., Natuna, D. A., \& Achmad, S. S. (2015). Pendidikan Seks dalam Keluarga Menurut Pandangan remaja. 7th International Seminar on Regional Education "Educational Community and Cultural Diversity", 486-495. Riau, Indonesia: Universitas Riau, Universiti Kebangsaan Malaysia. $\quad$ Retrieved https:/ / isre.prosiding.unri.ac.id/index.php/ISRE/article/view/3066

Rahim, A. R. (2011). Nilai-nilai utama kebudayaan Bugis. Yogyakarta: Ombak.

Rahman, A. (2014). Seksualitas Dan Kearifan Dalam Budaya Bugis. Walasuji: Jurnal Sejarah dan Budaya, 5(1), 47-59. 
Rosyid, M. (2007). Pendidikan Seks, Mengubah Seks Abnormal Menuju Seks yang Lebih Bermoral. Semarang: Syiar Media Publishing.

Sa'abah, M. U., \& Malian, S. (2001). Perilaku seks menyimpang dan seksualitas kontemporer umat Islam. Yogyakarta: UII Press.

Safita, R. (2013). Peranan orang tua dalam memberikan pendidikan seksual pada anak. EDUBIO: Jurnal Pendidikan Biologi, 4(1), 32-40.

Sarlito, W. S. (2012). Psikologi Remaja. Jakarta: PT. Raja Grafindo Persada.

Sarwono, S. W. (2010). Psikologi Remaja (Revisi). Jakarta: Rajawali.

Satria, E. D., \& Elsera, M. (2017). Tinjauan Sosiologis Penyebab Terjadinya Pelecehan Seksual terhadap Anak dibawah Umur oleh Remaja (Skripsi). Universitas Maritim Raja Ali Haji. Retrieved from http://jurnal.umrah.ac.id/wp-content/uploads/gravity_forms/1ec61c9cb232a03a96d0947c6478e525e/2017/02/JURNAL11.pdf

Septiawan, M. H., Pitoewas, B., \& Yanzi, H. (2014). Pengaruh Pendidikan Seks Dalam Keluarga Terhadap Perkembangan Moral Anak. Jurnal Kultur Demokrasi 2(8). Retrieved from http://jurnal.fkip.unila.ac.id/index.php/JKD/article/view/5967

Siahaan, B. A. (2015). Representasi Seksualitas Dalam Situs Jejaring Sosial Camfrog (Studi Semiotika Representasi Unsur-Unsur Seksualitas dalam situs jejaring sosial camfrog) (Skripsi). Sekolah Tinggi Ilmu Komunikasi Almamater Wartawan Surabaya. Retrieved from https:/ / eprints.stikosa-aws.ac.id/180/

Sifa, A. L. (2019). Peran Orang Tua dalam Pendidikan Seks Remaja (Studi Kasus Siswa Kelas VIII SMP Negeri 5 Salatiga) Tahun 2019 (Skripsi). Institut Agama Islam Negeri Salatiga. Retrieved from http:/ / e-repository.perpus.iainsalatiga.ac.id/6145/

Simon, L., \& Daneback, K. (2013). Adolescents' use of the internet for sex education: A thematic and critical review of the literature. International Journal of Sexual Health, 25(4), 305-319. https:/ / doi.org/10.1080/19317611.2013.823899

Sulaiman, A. (2016). MEMAHAMI TEORI KONSTRUKSI SOSIAL PETER L. BERGER. Society, 4(1), 15-22. https:/ / doi.org/10.33019/society.v4i1.32

Sulandjari, R. (2017). Literasi Media Sebagai Pengantisipasi Pelecehan Seksual Pada Anak dan Remaja (Studi Kasus di Kelurahan Pudakpayung Kecamatan Banyumanik Kotamadia Semarang). Majalah Ilmiah Inspiratif, 2(3). Retrieved from http://jurnal.unpand.ac.id/index.php/INSPI/article/view/634

Ulfiah, U. (2016). Psikologi Keluarga: Pemahaman Hakikat Keluarga dan Penanganan Problematika Rumah Tangga. Bogor: Ghalia Indonesia.

\section{About the Author}

A. Octamaya Tenri Awaru, obtained her Doctoral degree from State University of Makassar, Indonesia, in 2019. The author is an Assistant Professor at the Department of Sociology Education, Faculty of Social Science, State University of Makassar, Indonesia.

E-Mail: a.octamaya@unm.ac.id 